\title{
IDEOLOGY AND PEDAGOGY: THE ROLE OF POLITICAL ENVIRONMENTS IN SHAPING EDUCATION CURRICULUM
}

\author{
Samiya Sabharwal \\ The Shri Ram School, Moulsari \\ DOI: 10.46609/IJSSER.2021.v06i03.023 URL: https://doi.org/10.46609/IJSSER.2021.v06i03.023
}

\begin{abstract}
The extreme polarisation of political ideologies in contemporary India has created a dichotomy in the people of the nation, and there is an urgent need to inquire about the manifestations of the same. Returning to the grassroots of where ideologies and an understanding of the world is acquired, it is essential to study how political environments can and do influence curricula, and its pedagogy, to truly comprehend where the polarisation in thought emerges and thrives. This paper will examine the role that political environments play, either deliberately or unknowingly, in the shaping of education curriculum. This research will be scrutinised with an understanding of political biases and propaganda, and provide possible solutions to create a curriculum that is perhaps consciously free from these prejudices.
\end{abstract}

Key Words: Ideology, Pedagogy, Environment, Education, capitalism.

\section{Introduction}

Civic education and critical pedagogy emphasize critical reflexivity, bridge the gap between learning and everyday life, make visible the connections between power and knowledge, and provide the conditions for extending democratic rights, values, and identities; at the same time, they draw upon the resources of history (Giroux, 2007).

Henry A. Giroux in his essay, 'Utopian Thinking in Dangerous Times' remarks upon the perils of neoliberalism, a space where the distinction between capitalism and democracy has been erased. He argues in the above excerpt that critical pedagogy as a philosophy of education, one that replaces traditional curriculum, is capable of reviving a political consciousness, instilling ideas of democracy and values, and highlighting the grave distinctions between democracy and capitalism. Just as curricula has the competency to shape political thought, political contexts too are capable of creating a large impact on curricula: "...education is already a space of politics, power, and authority" (Giroux, 2007). As these two ideals of education and political consciousness are highly interdependent on one another, through this paper, I would like to 


\section{International Journal of Social Science and Economic Research}

ISSN: $2455-8834$

Volume:06, Issue:03 "March 2021"

investigate the role that political environments play, either deliberately or unknowingly, in the shaping of education curriculum.

It is essential to study this statement as the ideological being of our country has moved towards an immense political polarisation (Masih et al, 2019) essentially pitting two extreme thoughts at war with each other, a symptom of the United States of America as well. This paper believes that in order to tackle this problem, it is essential to revisit the role that a political environment can play in reassuring this polarisation, from the root of learning and pedagogy. This paper will be divided into two parts, and begin with providing a background to this study, an examination of the ways in which curriculum is exclusive, and how this exclusion is politically motivated as a kind of propaganda. The second part of this paper will move onto discussing the culmination of political environments in both humanities and the sciences, concluding how curricula can be protected from the discrimination within political environments.

\section{Background}

An early sign of the effect of political environments on education is the manner in which educational institutes practice exclusion, essentially deciding who will have access to education and who will not. According to Oxfam India, an international charitable organisation, exclusion in education is largely practiced within six parameters: class, caste, language, gender, geography and disabilities. Discussing the parameter of language here, there has been a gradual decline in the number of languages used as a medium of instruction from 80 in 1981 to 34 in 2009. Less dominant languages have been neglected contributing to the sense of alienation of tribal learners" (Taneja, 2020).

The eradication of languages does not only have cultural consequences, but also has serious repercussions on who has access to information, and who can essentially enter the public sphere of education. While exclusion in education, and in this context, language, does not appear as an effect of the political environment around us, the notion that powerful structures decide who has the opportunity to learn and who does not is a symptom of the politics that thrive in our societies, and hence, in the educational institutes that are a product of these societies.

This exclusion does not limit itself to the expulsion of individuals from educational institutes, but also culminates in the curriculum that is taught, or rather, not taught. The notion of exclusion is therefore twofold in this process, where there is a disbarring of certain people as well as curricula, to perhaps further political agendas. In early July 2020, while the country was still grappling with the multidimensional consequences of the Coronavirus pandemic, the Government ordered for a shortening of the syllabus, consequently furthering exclusions to achieve a homogenous ideology. According to an article published by the National Herald India, 


\section{International Journal of Social Science and Economic Research}

ISSN: $2455-8834$

Volume:06, Issue:03 "March 2021"

the Government, owing to the shutdown of education institutes during the pandemic, decided to exclude topics on democratic rights, structure of the Indian constitution, India's relations with its neighbours, food security, demonetisation, citizenship, secularism, caste, religion, gender et cetera, from The Central Board of Secondary Education (National Herald, 2020). Under the garb of reducing syllabus for students during the shortened school year, the Government specifically eliminated certain topics from the curriculum; and if one carefully scrutinises over these topics, these matters are known to be of recent, radical contestation in the country. Moreover, these recommendations that caused thirty percent of the syllabus to be eradicated were made by an autonomous body set up by the Government in 1961, The National Council of Education Research and Training (NCERT), which functions under the jurisdiction of the Government.

The above example states the politics of exclusion that the current Government has been practicing, however, this is not the first-time curriculum has been altered to serve political interests. This expedient has been adopted by multiple governments in the past, essentially attempting to remould history to promote their ideologies, and consequently, their political policies. For example, in one incident, an $8^{\text {th }}$ grade textbook in a school in Rajasthan was glorifying the inhumane practice of Sati, and in another, Vasundhara Raje, the former Chief Minister of Rajasthan in 2016 had removed Jawaharlal Nehru's name as the first prime minister of the country (Kidwai, 2019).

The implementation of curriculum as propaganda is not a phenomenon only unique in India, and has been used as a political weapon in various other nations. During the Israeli-Palestinian conflict that began in the mid-twentieth century, the representation of the 'other' in one or the other nation's textbooks is of great concern. As Israel grew towards a Zionist ideology, one that asks for the re-initiation of a Jewish state, the representation of Palestinians in Israeli-Jewish history and geography textbooks advocated stereotyping and prejudice (Elhanan, 2012), essentially propagating the idea of hatred in the minds of the Israeli people. In Palestine in Israeli School Books, the author comments upon the simple act of propaganda of not calling Palestinians by their name in Israeli textbooks, to further their agenda of keeping the IsraeliPalestinian conflict going: "In Israeli social, political and educational discourse Palestinian citizens are called by the demeaning label 'Israel's Arabs"' (Elhanan, 2012). By not referring to Palestinians as Palestinians in educational discourse, and assigning a demeaning label to them, the pitting of Israel's youth against the other commences at a young age, and this is a prime example of the uncomplicated manner in which curriculum can be slightly altered to create ample noise of propaganda.

\section{Discussion}




\section{International Journal of Social Science and Economic Research}

ISSN: 2455-8834

Volume:06, Issue:03 "March 2021"

Considering the examples stated above, one must assume that an education that is more liberal or left leaning, such as the field of the humanities must be free from such prejudices and biases, but that is a premature opinion to form. As social scientists and scholars of humanities form the mass of curriculum, it is first essential to ask the question, who is a social scientist, and what experiences have they gathered in their lifetime? A qualitative study of biases in social sciences was presented in a research in the context of the United States of America, "African Americans are underrepresented (in the social sciences) by about $70 \%$ and conservatives are underrepresented by almost 90\%" (Honeycutt et al, 2020). It is important to understand that social scientists and scholars of humanities pursue a certain research area due to the experiences they have had in their lifetime, and the fact there is scarce diversity in the field implies that the positions researchers argue for or against are more often than not unidimensional.

Apart from the somewhat obvious bias of who becomes a researcher and the experiences they bring into their studies, there exists a political bias in how researchers interpret findings that disprove their arguments. Even though researchers may come across studies that act as limitations to their arguments, they choose to interpret and present the studies in a manner that derogates them (Honeycutt et al, 2020). For example, if a researcher is attempting to prove the harmful effects of plastic, and comes across a study that proves how affordable the material is in a country such as India, they may present it in a way that shows how morally degraded the study is. Rather than accepting it as a limitation of their study and incorporating the same in a manner that both respects and accepts the economic restraints of the country, the researcher may simply attack the study for its anti-environmental stance.

The unceasing bias in the humanities and social sciences is proof that an impartial comprehension of the field is not possible, and that perspective especially defines this stream of thought. However, what about fields that are inherently based on a true-false scale of measure? Can they too be influenced by political forces?

In $20^{\text {th }}$ century Soviet Union, Trofim Lyensko, an agronomist and biologist birthed and propagated pseudoscientific notions of Lysenkoism. Essentially a political stance, Lysenkoism favoured Lamarckism over natural selection; a belief that an organism can pass off characteristics that they have acquired during their lifetime (genes of which they do not possess) to their offspring (Lerner, 2001). A scholar at the Harvard University, K. Lee Lerner interprets this precedency of the theory as politically motivated, as the pseudoscientist rejected differing explanations to his experiments, owing them all to unexplainable "revolutionary leaps" (Lerner, 2001). The true political impact during this time of misinformation was with the victory of Joseph Stalin in the elections, "Under Stalin and Lysenko, scientific truth became both incompatible and inappropriate to political truth" (Lerner, 2001). Comprehending Lyensko's ideas as the truth, Stalin omitted genetics as a topic from biology textbooks in Soviet. With 


\section{International Journal of Social Science and Economic Research}

ISSN: $2455-8834$

Volume:06, Issue:03 "March 2021"

absolute support from the Government, Lysenko was the orchestrator of many violent deaths and arrests of scientists who wished to criticise Lysenkoism (Lerner, 2001).

From a metaphysical standpoint, the incorporation of propaganda in curriculum is inevitable, as bias operates within all spheres of writing, reading, and even pedagogy. However, there are positions a curriculum can adopt within the limitations that it operates within, to at least consciously ensure that no biases are formed. After the end of the Nazi rule in Germany, the misuse of civic education as a form of propaganda was a fire that desperately needed to be put out. The 'Beutelsbach consensus' that was derived in 1976 by pedagogues and political scientists was one such extinguisher that set in stone the legitamation of political education, "only if it is not exploited for political purposes" (Kloubert, 2018). Beutelsbach consensus assured that overwhelming a pupil for the sake of personal opinions is prohibited, treating a controversial topic as controversial is a must, and that a pupil must be asked to analyse political situations against the backgrounds of their own personal interests (Kloubert, 2018). While this is a conversation from post-war Germany, the fight against propaganda in education is strengthened in Finland as well, that too from the grassroots of primary schools. Students in Finland are taught about notable propaganda campaigns across the world, and how words can often be incorporated to "confuse, mislead and deceive" (Henley, 2020). With the curriculum set for them, students are encouraged to become active and critical voters who can see through propaganda and hold responsible political opinions (Henley, 2020).

\section{Conclusion}

Political environments manifest themselves in education curricula in a wide variety of ways. It might be through the effort of excluding individuals, as well as parts of curriculum that do not fulfil political goals, by altering minor details that cause communities to hate one another, or through the implication of deliberate or unintentional biases. One can conclude that the influence of political environments on education curricula are massive, and any institution, irrespective of whether it exists in the public or the private sphere, is bound to be under the influence of the political.

This paper, while uncovering the effects of political environments on curricula also brings to attention two ways in which these consequences can be moderated. Again, while from a metaphysical standpoint, the notion of objectivity cannot be achieved under any circumstance, but, if there is a conscious effort in pedagogical methods, as well as the formulation of policies, political bias and propaganda in curriculum could be reduced. For example, in the case of Finland, the Government is devoted to the fight against falsity and propaganda in news items, and their primary goal is to create "active, responsible citizens and voters" (Henley, 2020). This instance of responsible pedagogical and learning is adopted to battle political influence from the 
International Journal of Social Science and Economic Research

ISSN: 2455-8834

Volume:06, Issue:03 "March 2021"

very core. Whereas in Germany, we now know how rigid policies determine this fight against political pressure. In the post-war nation, there is a commitment towards presenting facts as they are, moreover, students are also encouraged to analyse their opinions based on their backgrounds. In the case of our country, both these methods of pedagogical and policy growth can be implemented to firstly create responsible voters, and to secondly, reduce the intense political polarisation that has gripped the country.

\section{References}

Giroux, H.A., (2007), 'Utopian Thinking in Dangerous Times: Critical Pedagogy and the Project of Educated Hope', in Mark Coté et al (Ed.), Utopian Pedagogy: Radical Experiments against Neoliberal Globalization, University of Toronto Press.

Henley, J, (29 January 2020), 'How Finland starts its fight against fake news in primary schools', The Guardian, https://www.theguardian.com/world/2020/jan/28/fact-from-fiction-finlands-newlessons-in-combating-fake-news

Honeycutt, N, et al, (2020), 'A Model of Political Bias in Social Science Research', An International Journal for the Advancement of Psychological Theory, Vol. 31, Issue 1, https://www.tandfonline.com/doi/abs/10.1080/1047840X.2020.1722600?journalCode=hpli20

Kidwai, R, (16 ${ }^{\text {th }}$ May 2019), 'Newly formed Congress governments on education detoxication drive in three states', ORF Online, https://www.orfonline.org/expert-speak/newly-formedcongress-governments-on-education-detoxification-drive-in-three-states-50913/

Lerner, K.L., (2001), 'Lysenkoism: A Deadly Mix of Pseudoscience and Political Ideology', Academia,

https://www.academia.edu/39758097/Lysenkoism_A_Deadly_Mix_of_Pseudoscience_and_Polit ical_Ideology

Masih, N, et al, (21 May 2019), 'U.S.-style polarization has arrived in India. Modi is at the heart of the divide', Washington Post, https://www.washingtonpost.com/world/asia_pacific/dividedfamilies-and-tense-silences-us-style-polarization-arrives-in-india/2019/05/18/734bfdc6-5bb311e9-98d4-844088d135f2_story.html

National Herald India, (9 July 2020), 'Lessons on Democratic Rights, Citizenship and Secularism dropped by CBSE', https://www.nationalheraldindia.com/videos/lessons-ondemocratic-rights-citizenship-and-secularism-dropped-by-cbse 
Peled-Elhanan, N, (2012), 'The Representation of Palestinians in Israeli School Books', in Palestine in Israeli School Books: Ideology and Propaganda in Education, I.B. Tauris and Co Ltd.

Taneja, A, (29 June 2020), 'How can India's education system escape the vicious cycle of inequality and discrimination', Oxfam India, https://www.oxfamindia.org/blog/how-can-indiaseducation-system-escape-vicious-cycle-inequality-and-discrimination

Tetyana, K, (2018), 'Propaganda as a (new) challenge as a civic education', European journal for Research on the Education and Learning of Adults, Vol. 9, Issue 2, https://www.pedocs.de/volltexte/2019/16139/pdf/RELA_2018_2_Kloubert_Propaganda.pdf 